\title{
PENGELOLAAN POTENSI LOKAL MASYARAKAT BANJARNEGARA MELALUI UKM BATIK DI GUMELEM, BANJARNEGARA, JAWA TENGAH
}

\author{
Retno Purwandari dan Budi Hartono *)
}

\begin{abstract}
ABSTRAK
Batik merupakan salah satu budaya Indonesia yang saat ini sedang menjadi salah satu pembicaraan di kancah Internasional. Mendunianya batik Indonesia tidak lepas dari peran batikbatik yang berada di seluruh nusantara, terutama batik Jawa. Salah satu kota yang masyarakatnya sudah ada yang menggeluti batik ialah Banjarnegara, khususnya di Gumelem, meskipun tidak setenar Pekalongan. Batik Gumelem ini dipengaruhi oleh batik dari wilayah Sokaraja.

Dua UKM Batik yang dirangkul pengabdi sebagai wujud pengelolaan potensi lokal adalah Batik "Mirah" dan "Giat Usaha". Dari hasil komunikasi antara perajin, pemerintah, dan pengabdi ditemukan beberapa permasalahan yang dimiliki oleh perajin, terutama faktor keterbatasan pengetahuan, keterampilan, dan alat-alat penunjang. Melalui program pengabdian masyarakat yang dilaksanakan perguruan tinggi diharapkan mampu memberikan solusi atas permasalahan perajin tersebut. Perguruan tinggi bisa lebih meningkatkan permasalahan teknis desain yang lebih laku di pasaran, teknik pewarnaan, dan manajeman produksi, sedangkan perajin lebih giat lagi meningkatkan kualitas produk dan menjalin mitra yang lebih maju untuk meningkatkan produksinya. Pemerintah daerah melalui program-programnya untuk memajukan perajin bisa memberikan kelonggaran fasilitas dalam berwirausaha.

Sebagai wujud solusi dari permasalahan UKM dilaksanakan beberapa kegiatan. Pelatihan desain motif batik secara manual diharapkan merangsang perajin lebih kreatif menciptakan motif batik bernuansa kekhasan lingkungan Gumelem, Banjarnegara. Pelatihan desain motif batik berbasis komputer ditujukan untuk mempermudah proses mendesain supaya lebih cepat dan kreatif. Pembuatan cap batik kayu dan pelatihan menggunakannya diharapkan mampu membekali perajin supaya lebih bisa meningkatkan produksinya dengan mengenalkan teknik cap batik yang memiliki kekhasan dibanding cap batik tembaga.
\end{abstract}

Kata Kunci: potensi lokal; UKM Batik; Gumelem, Banjarnegara

\section{ABSTRACT}

Batik is the one of Indonesian culture that being trending topic in the world recently. A global Indonesian Batik can't ignore Batiks Nusantara role, especially Javanese Batik. The small city whose community already working Batik is Banjarnegara, actually at Gumelem, although not a well-known like Pekalongan. Gumelem batik gets influence from Sokaraja Batik.

Two Batik Small and Medium Enterprises which invited as a form of management local potential are "Mirah" and "Giat Usaha" Batik. From the communication between handicraft workers, government, and volunteers, several problems were found owned by handicrafts workers, especially the lack of knowledge, skill, and supplementary equipment. Through the program of devotion the community that were held college are expected to provide solutions to the problems handicraft workers. College could further improve technical issues design more

*) Arif Suharson (arifkeramos@yahoo.com), Staf Pengajar Program studi Kriya Seni, Jurusan Kriya, Fakultas Seni Rupa, Institut Seni Indonesia Yogyakarta. 
deportment in the market, staining technique, and management production, while handicraft workers harder to improve the quality of products and develop a partner that more advanced to increase production. Local government through its programs to advance handicraft workers can give a respite of facilities on business activities.

As a solution of Batik Small and Medium Enterprises carried out some activities. Training design a batik manually expected to stimulate handicraft workers more creative created a batik specialties Gumelem nuance. Training design a batik based on a computer intended to ease the process design to be faster and creative. Making wood batik stamps and training to use it is expected the handicraft workers to be more easily to increase production with the introduction batik stamp technique that has unique value than copper batik stamp.

Keywords: local potential; Batik Small and Medium Enterprises; Gumelem, Banjarnegara

\section{PENDAHULUAN}

Banjarnegara merupakan salah satu kabupaten di Jawa tengah yang terkenal dengan dawetnya, dawet Banjarnegara. Namun siapa sangka, ternyata Banjarnegara juga menyimpan potensi lokal, yakni batik, meskipun tidak setenar Pekalongan. Batik Banjarnegara ini merupakan salah satu budaya lokal yang dipengaruhi dari batik yang sudah ada di wilayah Sokaraja.

Usaha membuat Batik di Banjarnegara dimulai sejak 1968, namun ditekuni oleh masyarakat pada tahun 2003, hingga sekarang berjumlah 201 orang perajin yang tergabung dalam delapan kelompok besar. Sebagian besar perajin adalah wanita yang meluangkan waktunya di sela-sela mengerjakan sawah atau tegalan. Setiap kelompok rata-rata memiliki tenaga kerja 5 sampai 15 orang. Usaha membuat batik ini tetap dilakukan meskipun harus membutuhkan biaya pengeluaran yang cukup tinggi, sebab pekerjaan membatik ini merupakan pilar ekonomi kedua setelah ekonomi dari mengolah tegalan. Mereka mengalami kesulitan pemasaran, sebab tidak seimbang antara biaya produksi dan harga jual produk. Rata-rata perajin berpendidikan SD,
SMP, dan SMA, oleh karenanya persoalan pengetahuan teknik produksi, pengetahuan bahan dan desain produk tidaklah dipahami dengan baik. Meskipun tingkat pendidikan mereka tidak tinggi, mereka bekerja secara totalitas dengan workshop dan perlengkapan tradisional apa adanya.

Melihat potensi tersembunyi tersebut, ada dua UKM Batik yang ada di Gumelem, Banjarnegara, yakni UKM Batik "Mirah" dan "Giat Usaha" untuk dirangkul mengembangkan kegiatannya dalam membatik.. Kedua UKM ini belum berkembang secara maksimal karena keterbatasan pengetahuan, keterampilan, dan alat-alat penunjang. Untuk meningkatkan usaha batiknya, perlu diprioritaskan pada pembekalan keterampilan desain motif batik secara manual dan berbasis komputer, dikenalkan alat cap batik terutama berbahan kayu, dan pembekalan keterampilan menggunakan cap batik kayu tersebut. Menurut Prasetyo, tahun 1860 telah dikenal cara membatik dengan menggunakan cap, yakni cap dari tembaga. Penggunaan cap batik dipercaya memudahkan pembatikan, terutama untuk menorehkan lilin di atas kain (2010: 28). 
Pelatihan dan partisipasi yang dilakukan melibatkan langsung masyarakat dan pemerintah, agar masyarakat merasa memiliki tanggung jawab bersama pemerintah dalam mengelola potensi lokal. Kegiatan pelatihan pengembangan desain motif batik secara manual, pelatihan desain motif batik dengan komputer, pengenalan cap batik kayu, dan pelatihan membatik dengan teknik cap kayu diharapkan mampu membekali perajin untuk lebih kreatif, inovatif mendesain motif batik dan mampu melakukan diversifikasi produk. "Membatik cap atau "ngecap" ialah pekerjaan membuat batikan dengan cara mencapkan lilin batik cair pada permukaan kain" (Susanto, 1980: 30).

Target yang ingin dicapai dari kegiatan ini adalah keterampilan mendesain motif batik secara manual dan dengan komputer, pengetahuan cap batik kayu, keterampilan teknik cap batik terutama cap kayu, dan produk batik. Sumber Daya Manusia yang berwujud tenaga kerja terampil dan mandiri merupakan harapan yang diingiinkan. Dalam pelatihan desain motif baik secara manual dan dengan komputer, serta pelatihan menggunakan cap batik kayu, para perajin mampu mempraktikkan secara antusias dengan hasil yang baik. Untuk itu, tercetaklah perajin batik yang mampu dan terampil dalam mendesain batik secara inovatif dan menggunakan teknik cap batik kayu dalam produksinya. Pengenalan alat cap manual seperti kayu lebih pas dalam pelatihan tahap awal, sebab bila manual sudah terkuasai maka menggunakan alatalat yang lain akan lebih mudah. Selain itu, para perajin mampu menghasilkan beberapa desain motif batik dari hasil pelatihannya. Desain motif yang ditekankan adalah desain motif dari hasil eksplorasi lingkungan sekitar perajin, wilayah Gumelem, Banjarnegara. Hal ini dimaksudkan untuk memunculkan kekhasan dari Gumelem, Banjarnegara yang bisa dikenal melalui motif batik. Hasil eksplorasi tersebut diwujudkan dalam sebuah motif batik, yang kemudian diaplikasikan ke dalam alat cap batik kayu yang digunakan sebagai praktik awal pembuatan batik cap, sampai terhasilkan produk batiknya.

Melalui tulisan ini, dipaparkan cerminan potensi-potensi lokal daerah yang masih memerlukan motivasi dan pembekalan untuk lebih bisa mandiri mengembangkan usaha produksinya. Para perajin daerah seperti perajin Gumelem, Banjarnegara ini, akan timbul kepercayaan dirinya apabila tersentuh oleh pemerintah dan pengabdi masyarakat yang peduli pada kemajuan mereka.

\section{Pertemuan dan Koordinasi sebagai Metode Pendekatan terhadap Perajin}

Pertemuan berkomunikasi dengan perajin merupakan salah satu metode sederhana untuk melakukan pendekatan dengan perajin. Pada saat terjun di lapangan, adakalanya bertemu dengan manusia dengan berbagai karakternya, dan tidak jarang mereka yang tidak terbiasa bersosialisasi dengan cukup baik, biasanya sulit untuk menerima kedatangan orang asing, apalagi berniat untuk mengenalkan hal baru. Pendekatan secara persuasif harus dilakukan untuk menghindarkan pemikiran negatif dari masyarakat perajin.

Pendekatan ini berupa komunikasi dengan cara berdiskusi yang dilakuan 
antara pihak perajin, pemerintah, dan pengabdi. Hal utama yang harus diketahui adalah mengenal karakter para perajinnya, apakah mereka bersifat terbuka atau tidak. Perajin batik yang ada di Gumelem ini, kebetulan terbuka dan antusias dengan kedatangan pemerintah dan pengabdi, sehingga cukup mudah untuk mengetahui permasalahan-permasalahan apa saja yang dihadapi perajin.

Oleh karena itu, pihak-pihak terkait saling bertukar pendapat merencanakan beberapa kegiatan yang bisa dilakukan. Kegiatan-kegiatan yang dilakukan diharapkan memberikan manfaat sebagai solusi atas permasalahan yang dihadapi. Oleh karena itu, pada kegiatan ini para perajin dan pemerintah memberikan masukan, seperti hal-hal yang mereka butuhkan untuk kemajuan UKM. Para perajin Gumelem juga mengutarakan permasalahannya, seperti keinginannya untuk lebih mampu mendesain motif batik supaya lebih kreatif. Karena ada beberapa perajin yang masih muda, mereka menginginkan untuk bisa memiliki kemampuan desain dengan berbasis komputer. Mereka sangat mengharapkan sekali, karena untuk mendapatkan kemampuan tersebut, setidaknya harus kursus dan mengeluarkan biaya. Untuk itu, dengan adanya pertemuan dan koordinasi ini, masyarakat perajin bisa memanfaatkan dengan sebaik-baiknya.

\section{Pengembangan Desain Motif Batik secara} Manual

Kegiatan ini dilakukan dengan memberikan ceramah untuk transfer pengetahuan tentang desain motif batik, sekaligus melatih pembuatan motif batik beserta pengembangannya secara manual, yakni menggambar dengan tangan. Para perajin mempraktikkan langsung dalam pembuatan desain motif batik. Perajin dirangsang untuk menciptakan motif batik dengan tema-tema khas Banjarnegara, seperti Dawet Banjarnegara. Menurut Yudhoyono (2010: 7), "sehelai kain batik mahaindah yang dibentang di hadapanku adalah suatu karya urunan dari begitu banyak penggiat batik yang telah menekuni keahliannya masing-masing secara turuntemurun, selama ratusan tahun, di dalam tradisi yang mengakar kuat di dalam budaya asli setempat".

Sekian batik yang ada di Nusantara, masing-masing memiliki ciri khas yang berbeda, karena setiap daerah memiliki keunikan, ciri khas, dan coraknya tersendiri (Sa'du, 2010:63). Begitu pula batik Gumelem ini memiliki ciri khas motif yang berusaha mengangkat ikon kedaerahannya.

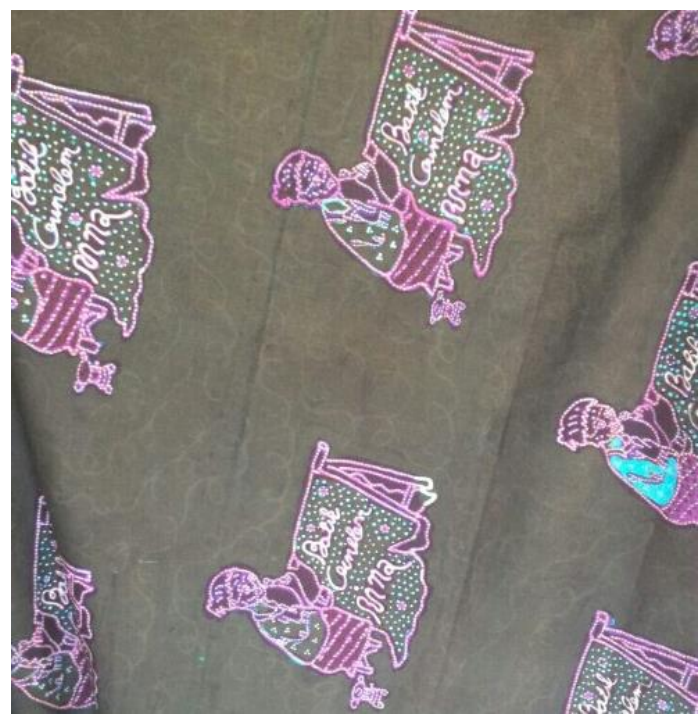

Gambar 1. Batik Khas Gumelem, Motif Batik Mirah (Sumber: Dokumentasi Retno Purwandari, diambil 12 September 2016 di Gumelem, Banjarnegara)

Perajin batik Gumelem sudah melakukan usaha membuat motif-motif 
batik dengan menampilkan kekhasan dari daerahnya. Pembekalan pengetahuan lebih difokuskan pada eksplorasi lingkungan di sekitar wilayah perajin.

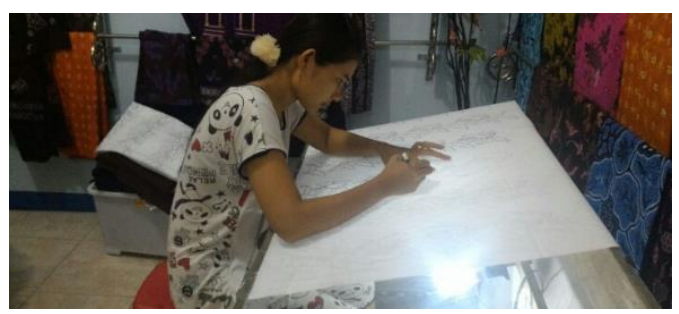

Gambar 2. Menggambar Motif Batik

(Sumber: Dokumentasi Budi Hartono, diambil 12 September 2016 di Gumelem, Banjarnegara)

Hasil eksplorasi yang dilakukan perajin menemukan bahwa untuk mengangkat dawet Banjarnegara, dibuatlah motif Dawet Wutah. Selain itu, dengan melihat faktor alam, para perajin menyoroti binatang manuk emprit 'burung emprit' yang begitu banyak di sekitar lingkungan perajin, maka diciptakan pula motif Emprit Ganthil 'Sepasang burung Emprit yang bersandingan atau berdempetan'. Yang tidak kalah menariknya adalah binatang katak. Katak, menurut perajin, sangat aktif bereproduksi di lingkungan sekitar, apalagi pada saat musim hujan, sehingga banyak ditemukan telur katak beserta kecebongnya. Untuk itu, dibentuklah motif Cebong Kumpul 'Kecebong berkumpul'.

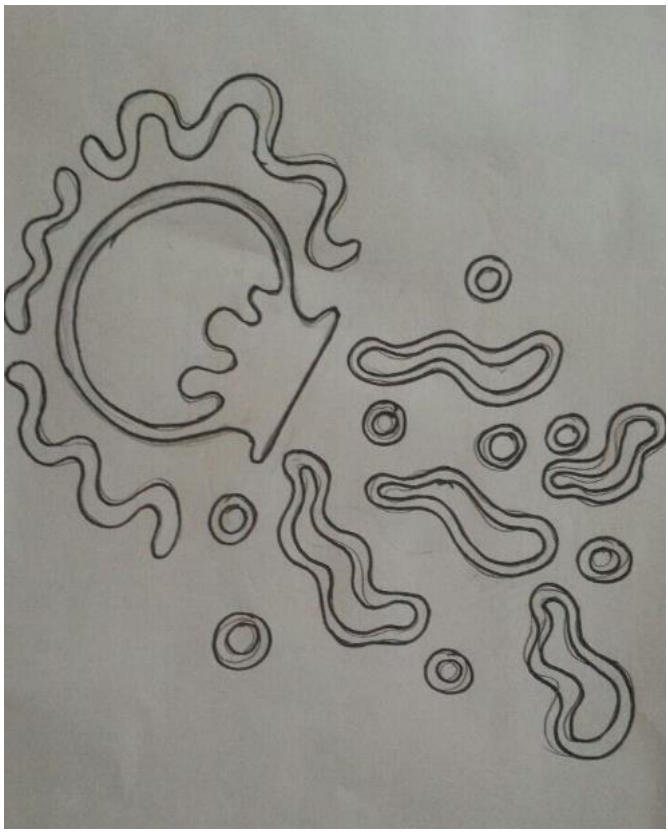

Gambar 3. Motif Dawet Wutah

(Sumber: Dokumentasi Budi Hartono)

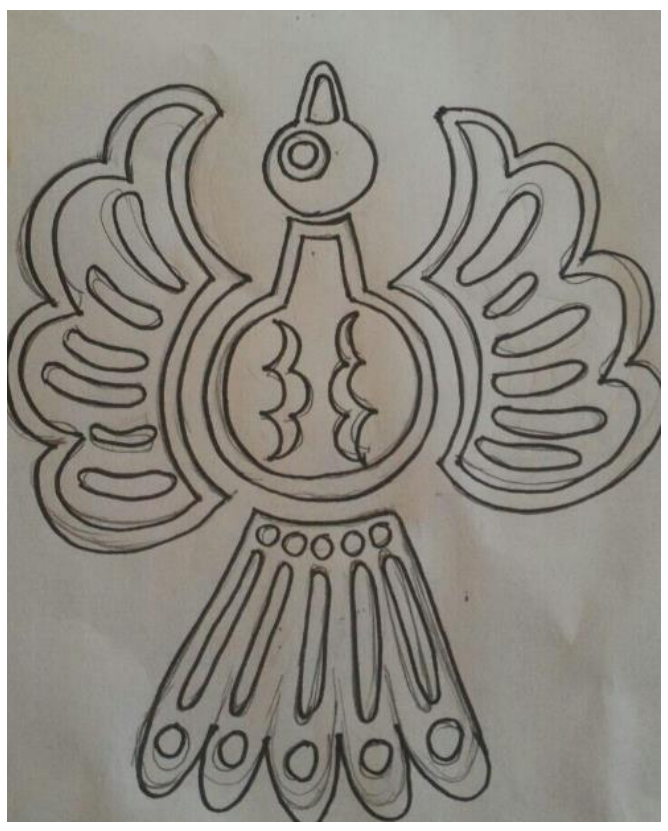

Gambar 4. Motif Emprit Ganthil

(Sumber: Dokumentasi Budi Hartono) 


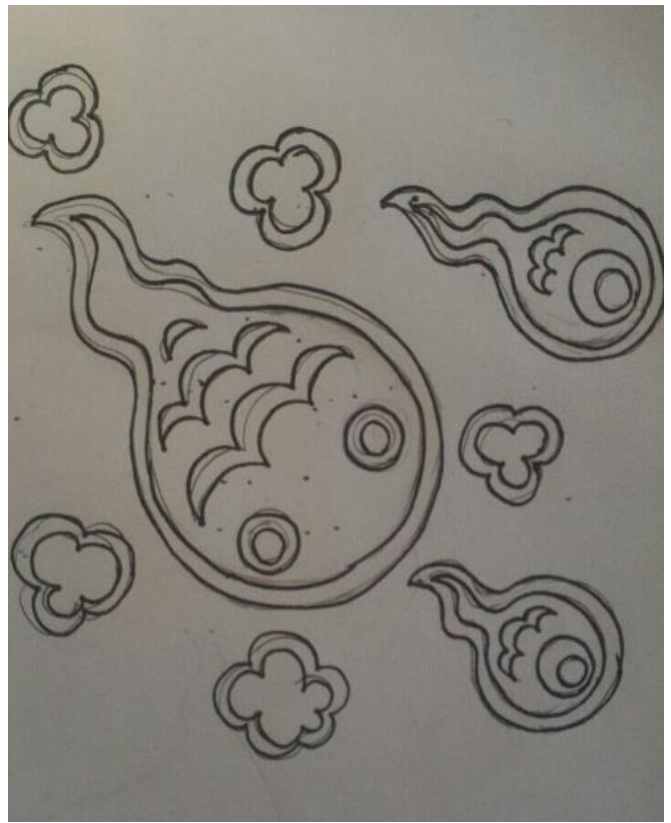

Gambar 5. Motif Cebong Kumpul

(Sumber: Dokumentasi Budi Hartono)

\section{Pengenalan Teknik Cap Batik Kayu}

Kegiatan ini mengenalkan teknik batik cap selain teknik tulis dengan metode ceramah dan diskusi. Selama ini perajin menekuni batik tulis. Untuk percepatan produksi, perajin dikenalkan dengan cap batik, khususnya cap batik kayu. Pembuatan cap batik kayu lebih murah dibandingkan cap batik tembaga. Selain itu, teknik cap batik kayu akan menghasilkan batik dengan kekhasan tersendiri, dikarenakan tekstur dari kayu tersebut. Cap kayu memiliki kelebihan "efek dekorasi serat kayu" yang berbeda dari cap batik logam. Masingmasing jenis batik berdasarkan tekniknya, seperti batik tulis, batik cap, batik printing memiliki kekhasan tersendiri (Sa'adu, 2010: 58).

Untuk mengenalkan cap batik kayu, motif-motif batik yang telah diciptakan oleh perajin atas arahan dari pembimbing diaplikasikan ke dalam wujud cap batik kayu. Cap batik kayu yang dibuat berdasarkan motif-motif baru kekhasan batik Gumelem diharapkan dapat segera dimanfaatkan perajin untuk mempraktikkan produksi batik.

Dari tiga motif batik yang tercipta, yakni motif Dawet Wutah, Emprit Ganthil, dan Cebong Kumpul dapat dibuat menjadi enam cap batik kayu, karena masing-masing motif bisa dibuat ke dalam dua versi cap batik kayu, yakni versi positif dan negatif.

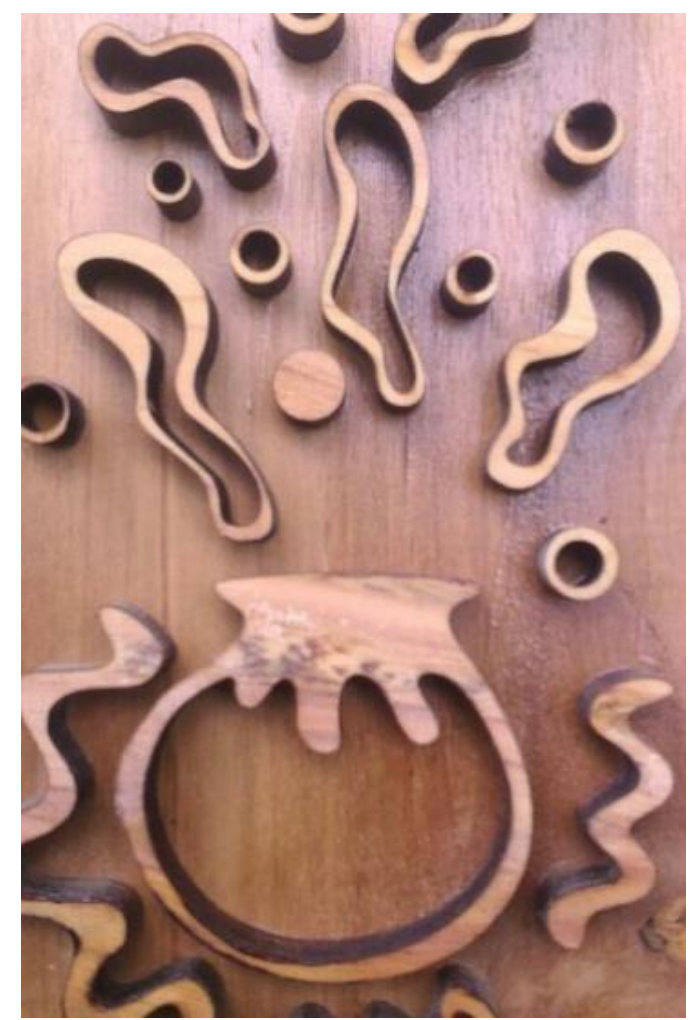

Gambar 6. Cap Batik Kayu Motif Dawet Wutah Versi Positif

(Sumber: Dokumentasi Budi Hartono) 


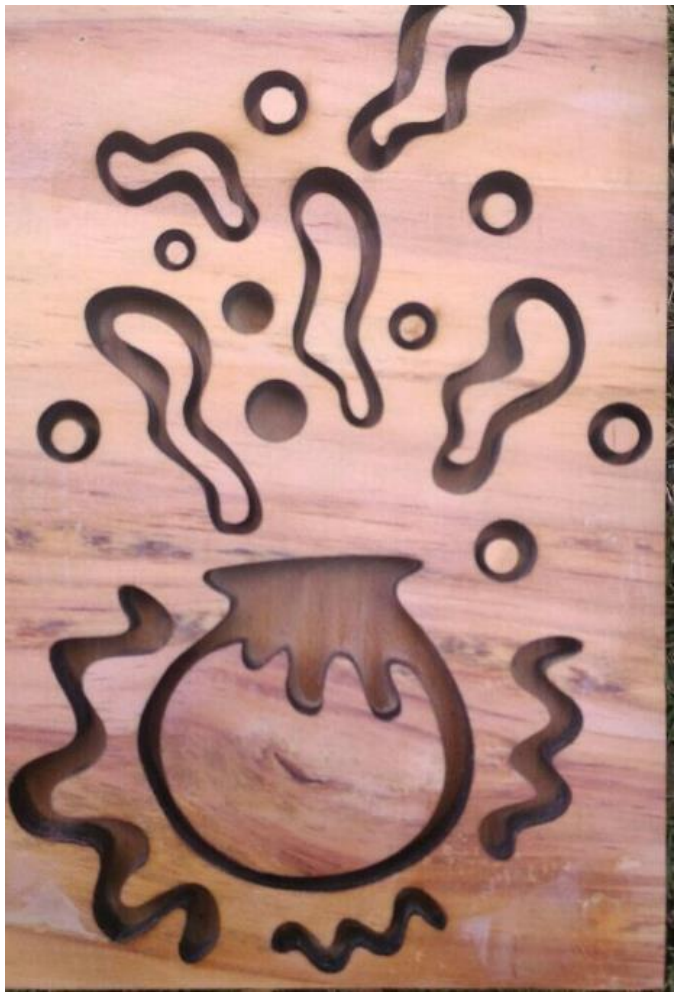

Gambar 7. Cap Batik Kayu Motif Dawet Wutah Versi Negatif

(Sumber: Dokumentasi Budi Hartono)

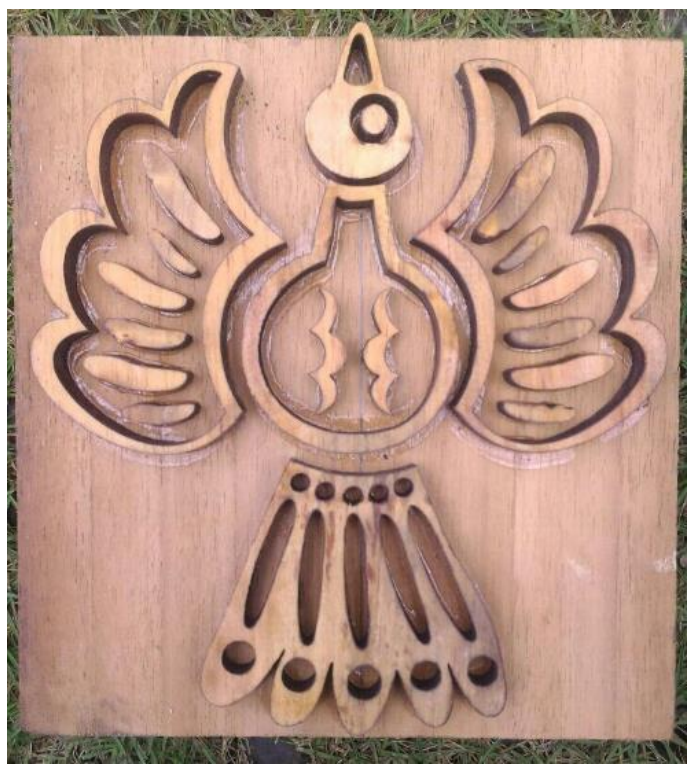

Gambar 8. Cap Batik Kayu Motif Emprit Ganthil Versi Positif

(Sumber: Dokumentasi Budi Hartono)

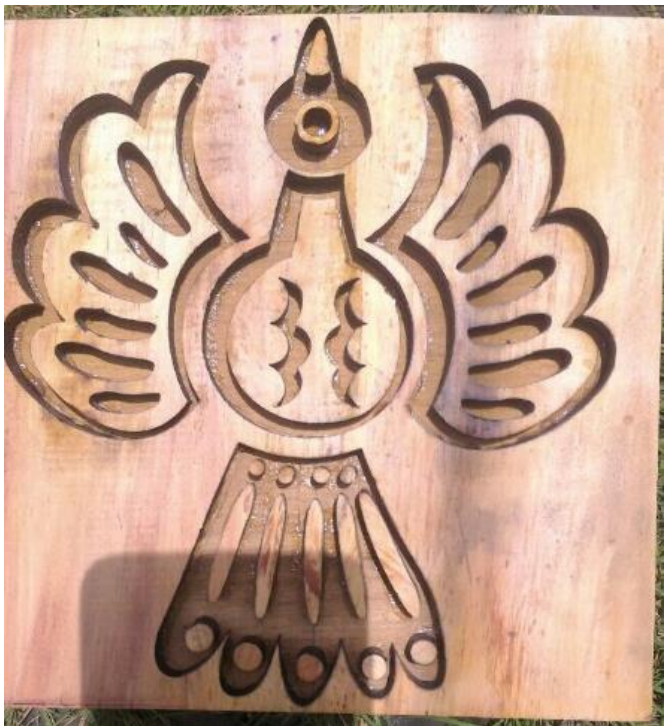

Gambar 9. Cap Batik Kayu Motif Emprit Ganthil Versi Negatif

(Sumber: Dokumentasi Budi Hartono)

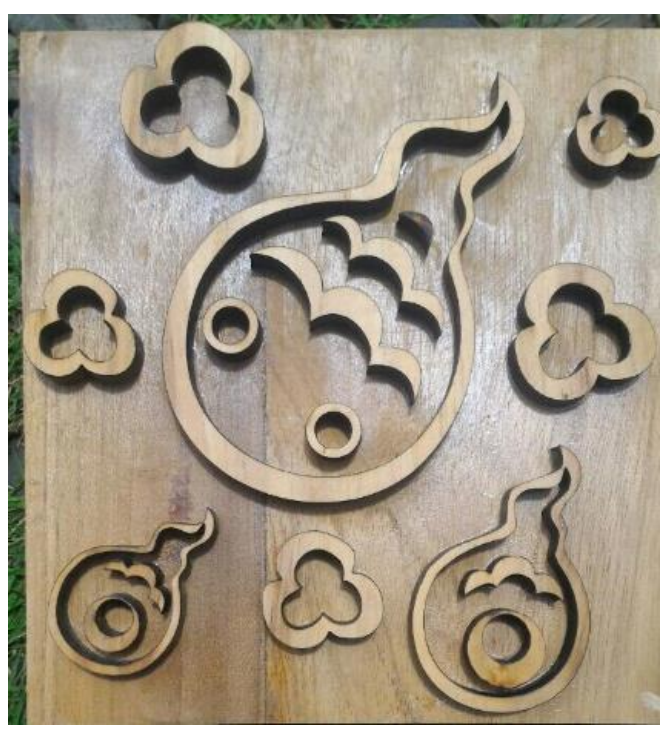

Gambar 10. Cap Batik Kayu Motif Cebong Kumpul Versi Positif

(Sumber: Dokumentasi Budi Hartono) 


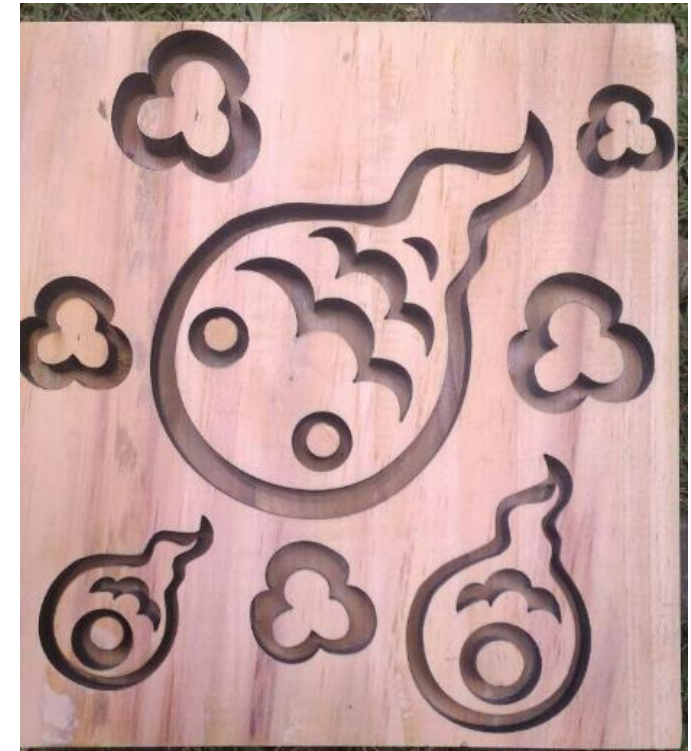

Gambar 11. Cap Batik Kayu Motif Cebong Kumpul Versi Negatif

(Sumber: Dokumentasi Budi Hartono)

\section{Pembuatan Produk Batik}

Kegiatan ini merupakan kerja praktik atas pelatihan yang telah didapatkan oleh para perajin, yakni pengembangan desain motif batik dan pelatihan membatik dengan teknik cap, khususnya cap kayu. Mereka mencoba mempraktikkan keterampilan yang telah didapatkan untuk membuat produk batik. Para Perajin sangat antusias dan tidak merasa kesulitan dalam mempraktikannya.

Dengan cap batik kayu yang disediakan, perajin bisa mengombinasikan antara cap batik satu dengan yang lainnya. Selain itu, mereka bisa mengombinasikan antara teknik batik tulis dengan teknik batik cap. Beberapa hasil produk batik yang telah mereka praktikkan adalah sebagai berikut:

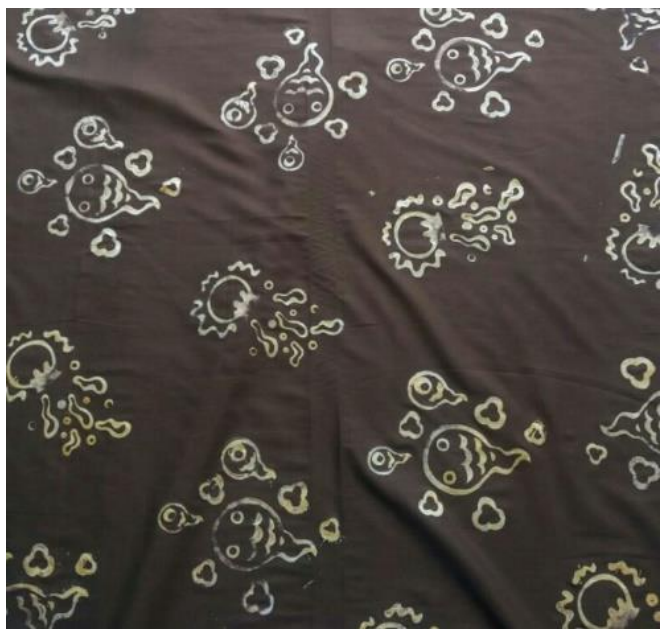

Gambar 12. Batik Dawet Wutah

(Dokumentasi: Budi Hartono)

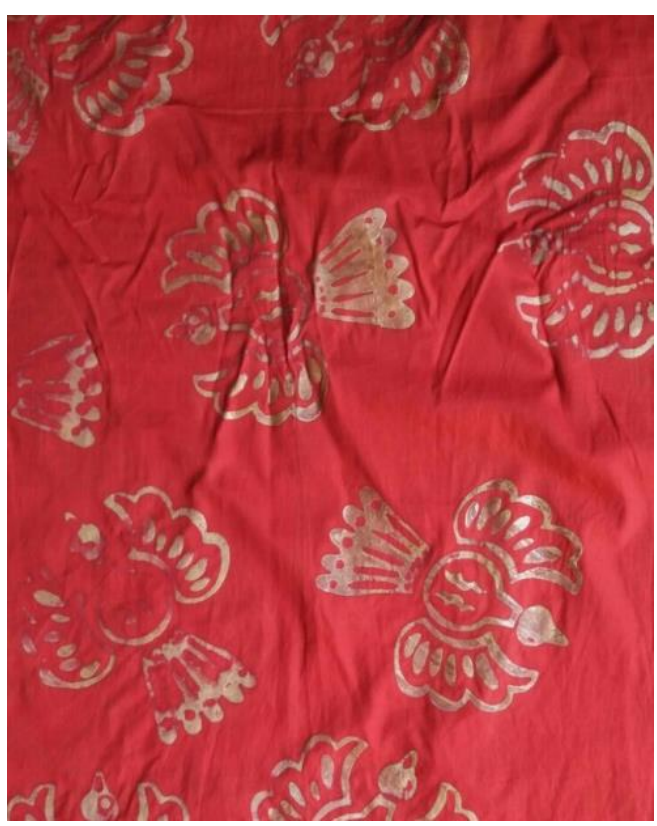

Gambar 13. Batik Emprit Ganthil

(Dokumentasi: Budi Hartono) 


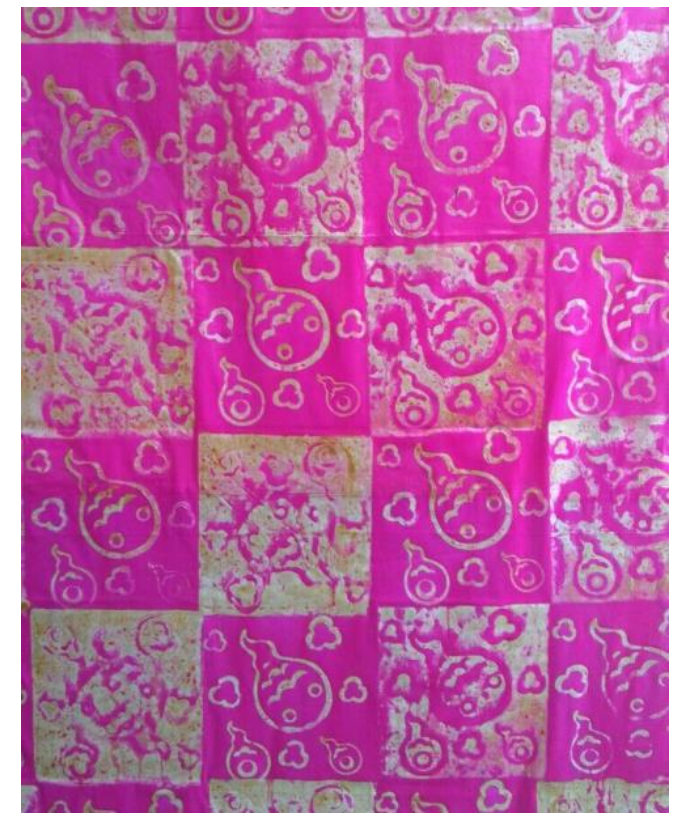

Gambar 14. Batik Cebong Kumpul

(Dokumentasi: Budi Hartono)

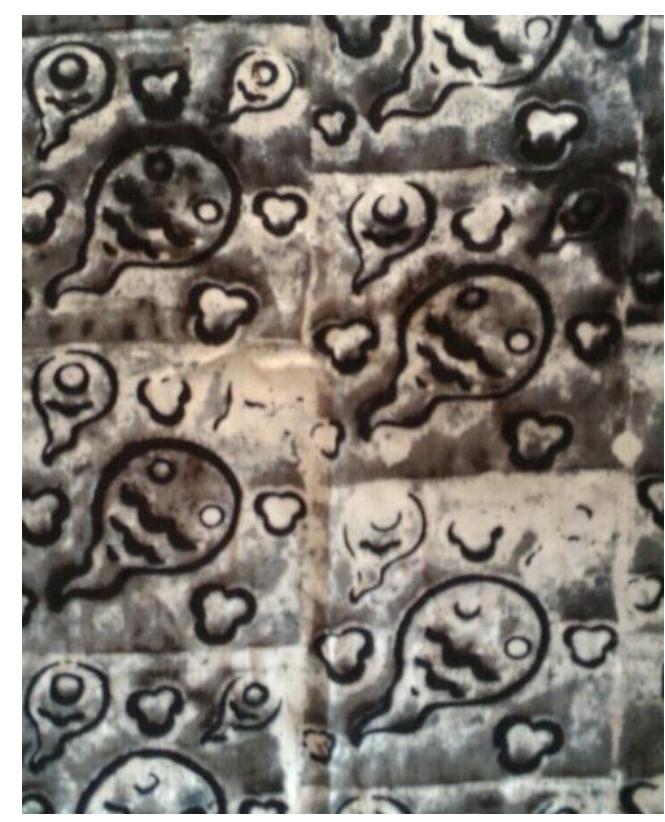

Gambar 15. Batik Cebong Kumpul

(Dokumentasi: Budi Hartono)

\section{PENUTUP}

Pelatihan dan partisipasi yang melibatkan langsung masyarakat merupakan metode yang tepat dan menguntungkan bagi pemerintah dan masyarakat, sebab dengan cara seperti itu masyarakat merasa memiliki tanggung jawab bersama pemerintah dalam mengelola potensi daerah. Sektor kerajinan batik memang sedang naik daun. Saat ini kerajinan batik merupakan aset baru bagi perekonomian masyarakat Banjarnegara, namun demikian masih banyak kekurangankekurangan yang perlu ditingkatkan secara serius, sebab belum dikelola dengan benar dan maksimal.

Rangkaian proses pelatihan ini diharapkan mampu membekali pengetahuan, pengalaman, dan keterampilan kepada perajin agar memicu pembuatan produk dengan desain kekinian dan mampu melakukan diversifikasi produk batik. Perajin bisa menciptakan berbagai jenis produk, seperti perlengkapan aksesoris, perlengkapan ruang makan dan ruang tamu. Kebaruan memiliki pengertian tidak harus berbeda dengan produk yang sudah ada, tetapi pembenahan motif, penambahan aksesoris, dan pengayaan warna-warna sebagai bagian dari proses diversifikasi.

Berdasarkan kegiatan yang sudah dilaksanakan ini masih banyak kendala dan kekurangannya seperti sulitnya mengumpulkan warga sekitar apabila pelatihan akan dilaksanakan. Kegiatan membatik hanya sebagai aktivitas sampingan yang tidak dikerjakan setiap saat, sehingga perajin tidak fokus dalam memajukan usahanya. Kurangnya pembinaan dari instansi pemerintah yang berkaitan dengan pengayaan desain, manajemen produksi, dan permasalahan teknis membatik.

Untuk meningkatkan kualitas alangkah baiknya antara perguruan tinggi, perajin dan pemerintah daerah mau bekerja 
sama secara berkesinambungan mengatasi kendala-kendala tersebut. Peran perguruan tinggi bisa lebih meningkatkan permasalahan teknis desain yang lebih laku di pasaran, teknik pewarnaan, dan manajeman produksi. Sedangkan perajin lebih giat lagi meningkatkan kualitas produk dan menjalin mitra yang lebih maju untuk meningkatkan produksinya. Pemerintah daerah melalui program-programnya untuk memajukan perajin bisa memberikan kelonggaran fasilitas dalam berwirausaha. Kreativitas dalam menciptakan desain baru masih lemah sehingga perlu beberapa solusi:

1. Pendampingan berkelanjutan;

2. Pelatihan desain secara khusus sehingga mampu mencipta desain sendiri;

3. Rekrutmen khusus tenaga di bidang kreatif desain.

Uji coba penggunaan cap batik kayu sedang disesuaikan dengan corak desain lokal, sehingga akan ditemukan corak yang pas dengan cap batik bermaterial kayu sengon atau kayu yang tidak mempunyai kandungan minyak.

\section{DAFTAR PUSTAKA}

Prasetyo, Anindito. 2010. Batik Karya Agung Warisan Budaya Dunia. Yogyakarta: Pura Pustaka.

Sa'du, Abdul Azis. 2010. Buku Panduan Mengenal \& Membuat Batik. Yogyakarta: Harmoni.

Susanto, Sewan. 1980.Seni Kerajinan Batik Indonesia. Balai Penelitian Batik dan Kerajinan, Lembaga Penelitian dan Pendidikan
Industri, Departemen

Perindustrian R.I.

Yudhoyono, Ani Bambang. 2010. Batikku Pengabdian Cinta tak Berkata. Jakarta: Kompas Gramedia. 